\title{
THE EFFECT OF ORGANIZATIONAL CITIZENSHIP BEHAVIOR AND COUNTERPRODUCTIVE BEHAVIOR ON EMPLOYEE PERFORMANCE WITH EMPLOYEE ENGAGEMENT AS AN INTERVENING VARIABLE IN BPR
}

\author{
Agustinus Setyawan ${ }^{1)}$, Agnes Triyanti ${ }^{2)}$ \\ ${ }^{1,2)}$ University of International Batam, Riau Islands, Indonesia \\ Corresponding author: agustinus.setyawan@uib.ac.id
}

\begin{abstract}
Banking is the one that provides services to customers in order to create a right image of a businessman. This research aims to analyze the impact of organizational citizenship behavior, counterproductive work behavior, and employee engagement as variable intervening through employee performance in Bank Perkreditan Rakyat in Batam. The difference in the behavior of each employee is a determinant of their performance in the company. They have increased the competition in the banking sector, which continues to compete to create better services. The behavior of employees has positive and negative that can be affected by colleagues around them. Positive behavior will affect good performance for the Organization, and hostile behavior will become an obstacle to an organization. Based on existing problems, this research needs to determine how employee behavior can be involved in their performance. Based on the author's survey, people who work at Bank Perkreditan Rakyat show employee behavior that needs to be considered in employee performance appraisal. By looking at several factors and the impact to these employees on the company. In general, the services provided to the financial services sector are essential aspects of the banking sector to improve the Organization's quality.
\end{abstract}

Keywords: Organizational Behavioral, Employee Performance, Employee Involvement, Counterproductive Work Behavior, Organizational Citizenship Behavior

\section{Introduction}

The competitive dimension between the financial services sector increases and changes for the better and more rapidly. However, to demonstrate this change, the banking industry has faced many challenges, especially in terms of products and services provided to customers. Many challenges arise from financial service companies such as Financial Technology (FINTECH), Corporate Social Responsibility (CSR), government agencies, and State-Owned Enterprises (BUMN), which continue to compete in reaching their segment, followed by commercial banks that on a mandatory basis to channel $20 \%$ of the total value of financing to Micro, Small and Medium Enterprises (MSMEs) and this will make the prospects for Rural Banks (BPR) more challenging in the future. Thus, the readiness of a company's core capital is critical to survive and have competitiveness.

Employees' contributions can be seen through daily behavior in the company and the scope of work that impact employee performance. Bank Perkreditan Rakyat (BPR) provides an excellent opportunity to employ the millennial generation in the company. With this, more and more employees have different qualities where employees are allowed to demonstrate each individual's value to improve the Organization's quality, which can be seen through changes in how to serve customers. Organizations believe that to get quality, and they have the right to create performance standards because, basically, individual performance will significantly affect performance in the team and ultimately affect the overall quality of performance in the Organization. However, beyond that, there are many individual behaviors in different organizations and outside formal work situations. Some individuals have attitudes that exceed performance standards by involving themselves in something outside their duties with significant initiatives to positively impact the Organization.

\section{Literature Review \\ Employee Performance}

Performance is doing a task in line with the job description, resulting in achievement following the perfection of what Rizwa et al. (2014) want. Employee performance is the achievement or measure of success or failure in the job, determined by various factors. Individual employee performance has a significant influence, both from individual employees (internal factors) or organizational environmental conditions (external factors), which are also the company's actions. The internal factors, for example, are motivation, expectations, goals, and others. And external factors, namely the scope of the inside and outside the company. Having a performance that one can be proud of is one of the achievements that the entire company as a whole wants. If employees perform their duties properly, they can provide individual achievements for the company. Vice versa, if the employee's performance is terrible, it will also harm the company (Ahmad et al., 2014). 


\section{Organizational Citizenship Behavior (OCB)}

Organizational Citizenship Behavior, namely employees' behavior, positively influences the Organization because they have unselfish behavior, but they are highly social beings. Employees like this have excellent performance, improving the company by being the Organization's driving force. This kind of behavior will make it easier to communicate and interact with organizational colleagues and minimize the obstacles to problems that can increase efficiency (Novliadi, 2016). Previous research linked Organizational Citizenship Behavior and Employee Performance was tested by researchers such as (Kambiz 2013) (Uddin, 2018).

\section{Counterproductive Behavior}

Based on (Ruky 2012), to calculate Employee Performance, a question is used that contains the characteristics of dimensions related to work. There are six-dimensional characteristics in order to be able to assess employees, namely self-quality, quantity, timeliness, cost-effectiveness, need for supervision, the interpersonal impact for employees who have high enough self-esteem in their work so that they have a sense of wanting to get the best results for their work is the level of the situation. the employee's behavior to create a comfortable work environment for himself. Piskin (2014) reported that Counterproductive Work Behavior is a form of behavior created by members of the Organization on purpose contrary to the Organization's goal.

\section{Employee Engagement}

As an emotional state, employee engagement refers to attention, motivation, and resilience in carrying out tasks. In contrast, as an act of behavior, employee engagement refers to concrete actions taken by employees who cross standard job specifications set by management to provide more or provide - the best for the Organization (Bagyo, 2016). Previous research related to employee engagement with employee performance was conducted with researchers (Uddin, 2018), (Madhura, 2013).

\section{Research Method}

This study's population consists of all employees at 5 (five) BPR in Batam with 360 employees. This study's samples consist of 360 employees who worked at 5 (five) BPR in Batam. This study uses a total sampling technique, using a questionnaire instrument. The method used is the Slovin method, and the data analysis is used in SPPS and PLS.

Organizational Work Behavior is more effort by individuals within a company that directly or indirectly increases organizational effectiveness, such as helping colleagues, doing volunteer duties, and obeying rules and procedures - organ et al. (2018).

Counterproductive Work Behavior can define all activities carried out by individuals in an organizational environment intentionally or not to interfere and harm the performance of those around them. This behavior can be understood as harmful to themselves, others, and the Organization (Bagyo, 2018). The list of questions regarding the Counterproductive Work Behavior questionnaire was adopted from the questionnaire developed by (Linda Koopmans, 2014).

According to Sedarmayanti (2011), employee performance is a unique way to get increased results in organizations, teams, and individuals to follow agreed goals and standards. Questions about Employee Performance are taken from a questionnaire developed with Irum Shahzadi. (2014).

Employee Engagement is an action to determine the extent to which individual involvement identifies their ability to work and participates in organizational activities to be involved in a variety of emotions, where their involvement is essential to improve the quality of the company Schaufeli (2013) List of statements regarding Employee Engagement is taken from The questionnaire developed by Bhavesh (2016).

\section{Result and Discussions Validity Test and Reliability Test}

Based on the results of the validity test below, it shows the overall AVE results, and four variables fall into the valid criteria because it has AVE values, namely organizational citizenship behavior (0.830), counterproductive work behavior (0.528), employee engagement (0.651), and employee performance (0.797).

The data processing reliability in the table below shows the calculation of composite reliability for the organizational citizenship behavior variable of 0.907 , counterproductive work behavior of 0.847 , employee engagement variable of 0.881 , and employee performance variable of 0.887 . These results show that all variables have composite reliability, a level higher than 0.70 Beckett et al. (2017).

\section{Hypothesis Testing}

Results of hypothesis testing in Table 1 show that $\mathrm{H} 1$ is accepted with a probability value of $0.000, \mathrm{H} 2$ is accepted with a probability value of $0.005, \mathrm{H} 3$ is accepted with a probability value of $0.000, \mathrm{H} 4$ is accepted with a probability values of 0.000 . In contrast, $\mathrm{H} 5$ is not accepted with a probability value of 0.140 . 
Table 1. Hypotheses Testing

\begin{tabular}{lccc}
\hline \multicolumn{1}{c}{ Variable } & T-Statistics & P-Values & Conclusion \\
\hline $\begin{array}{l}\text { Organizatuinal Citizenship Behavior } \\
\text {-> Employee Performance }\end{array}$ & 8,134 & 0,000 & H1 is accepted \\
\hline $\begin{array}{l}\text { Organizatuinal Citizenship Behavior } \\
\rightarrow \text { Employee Engagement }\end{array}$ & 8,241 & 0,000 & H2 is accepted \\
\hline $\begin{array}{l}\text { Employee Engagement -> } \\
\text { Employee Performance }\end{array}$ & 5,251 & 0,000 & H3 is accepted \\
\hline $\begin{array}{l}\text { Countraproductive Work Behavior - } \\
>\text { Employee Engagement }\end{array}$ & 11,146 & 0,000 & H4 is accepted \\
\hline $\begin{array}{l}\text { Countraproductive Work Behavior - } \\
>\text { Employee Performance }\end{array}$ & 1,478 & 0,140 & H5 is not accepted \\
\hline
\end{tabular}

According to the number of calculated path analyses, the T-Statistic results of organizational citizenship behavior are higher than 1.96, so organizational citizenship behavior has a significant relationship to employee performance. This relationship can be analyzed for its significance because employees who do work outside the Organization's demands and responsibilities voluntarily aim to help and will affect good employee performance. The test results are in line with Bagyo's research (2018), which shows that organizational citizenship behavior is significantly connected to employee performance.

Based on the results of the path analysis, the T-Statistic Counterproductive Work Behavior results are low than 1.96; counterproductive work behavior has a negative effect and has no significant relationship to employee performance, causing members who have deviant behavior by consciously choosing to engage in harmful behavior that can interfere with organizational continuity and will make their performance worse. The test results are in line with those tested by Bagyo (2018), which shows that counterproductive work behavior harms employee performance.

Based on the path analysis calculation, the T-statistic results of organizational citizenship behavior were more significant than 1.96; then, organizational citizenship behavior has no significant relationship to employee engagement. This relationship can be interpreted that employees who have this behavior who perform voluntary work will involve employees in every Organization aimed at corporate welfare. This test is in line with the results of the Bagyo test (2018). where showing organizational citizenship behavior has a relationship to employee engagement.

Based on the path analysis results, the T-Statistic results of counterproductive work behavior were more significant than 1.96. Counterproductive work behavior has a significant relationship to employee engagement, which causes its significance to be employees who take negative actions on purpose and engage in actions that can harm themselves. The test results are not in line with Bagyo's research (2018), which shows that counterproductive work behavior is negatively related to employee engagement.

The path analysis calculation shows the T-Statistic results for the variable employee engagement of 1.96; then, Employee engagement has a significant relationship with employee performance. This engagement causes the significance of members who have enthusiasm for work and fully perform at their best, which can have a positive impact on the organization and performance appraisals. This test is in line with the test results from Bagyo (2018), which shows that employee engagement has a significant relationship to employee performance.

\section{Conclusion}

The findings show that organizational citizenship behavior has a significant effect on employee performance and employee engagement. Employee engagement has a significant effect on employee performance. Counterproductive behavior has a significant effect on employee engagement. In contrast, counterproductive behavior harms employee performance.

\section{References}

Agung, I. G., Prabasari, M., Kadek, L., Martini, B., \& Suardika, N. (2018). The Effect of Communication and Employee Engagement on Organizational Citizenship Behavior and Employee Performance PT PLN in Bali Distribution of Bali. 9, 21014-21025.

Ahmed, M., \& Dajani, Z. (2015). The Impact of Employee Engagement on Job Performance and Organizational Commitment in the Egyptian Banking Sector. 3(5), 138-147. https://doi.org/10.12691/jbms-3-5-1

Ahmed (2012). Exploration of Predictors of Organizational Citizenship Behavior and link to Employee Engagement in Arab Saudi https://doi.org/10.1108/13287261311322602

Ahmad, Ben Mrad, S., \& O'Leary, B (2014). The Relationship between Employee Performance, Organizational Citizenship Behavior, and Counterproductive Work Behavior. 4(2), 46-56. https://doi.org/10.5430/ijba.v4n2p46 
Alfes, K., Shantz, A. D., Truss, C., \& Soane, E.C. (2013). The Link between Organizational Citizenship Behavior and Human Resource Management Practices on Employee Engagement as an intervening variable.

Aladenusi, Joshi, M., \& Jadiva, N. (2014). Counterproductive Behavior and Job Performance among secondary school teachers: School Climate as a Mediator 9, 21014-21025.

Ariani, D. W. (2013). The Relationship between Employee Engagement, Organizational Citizenship Behavior, and Counterproductive Work Behavior. 4(2), 46-56. https://doi.org/10.5430/ijba.v4n2p46

Bagyo, P. Y. (2018). The Effect of Counterproductive Work Behavior ( CWB ) And Organizational Citizenship Behavior ( OCB ) on Employee Performance With Employee Engagement As Intervening Variable. 20(2), 83-89. https://doi.org/10.9790/487X-2002048389

Bedarkar, M., \& Pandita, D. (2014). A study on the drivers of employee engagement impacting employee performance. Procedia - Social and Behavioral Sciences, 133, 106-115. https://doi.org/10.1016/j.sbspro.2014.04.174

Bhavesh. \& Zake. J. (2016). The Mediating Role of Employee Engagement between the relationship of Distributive Justice and Organizational Citizenship Behavior., 2(11),494-500.

Chelagat, L. J., Box, P. O., \& Kiprop, P. (2015). Effect of Organizational Citizenship Behavior on Employee Performance in Banking Sector, Kenya. 5(4), 55-61.

Chand, \& Djavi, Z (2014). Management \& Business Excellence Effects of organizational citizenship behavior on quality performance in the workplace

Devonish, D. (2012). The effect of workplace bullying, Work-Related Depression as a meditation on Task Performance. https://doi.org/10.1108/ER-01-2013-0004

Eldor \& Harpaz (2016). A process model of Extra Role Performance Behaviors on Employee Engagement in Company, Israel. 235(May 2015), 213-235. https://doi.org/10.1002/job

Eeman, T. Z. (2016). Impact of organizational Citizenship behavior on Job Performance in India Health Care Industries. 2(1), 14-32.

Guan, X., Frenkel, S., Guan, X., \& Frenkel, S. (2018). Performance How HR practice, work engagement and job crafting performance. https://doi.org/10.1108/CMS-11-2017-0328

Gupta, M., Acharya, A., \& Gupta, R. (2015). Impact of Work Engagement on Performance in Indian Higher Education System. 7(3), 192-201. https://doi.org/10.5539/res.v7n3p192

Hanzaee, K. H., \& Mirvaisi, M. (2013). Management Science Letters. 3, 1395-1402. https://doi.org/10.5267/j.msl.2013.04.010

Hanzaee, K. H., \& Mirvaisi, M. (2013). A survey on Impact of Emotional Organizational Citizenship Behaviors and Job Satisfaction in Employee Performance in Iranian Hotel industry 3, 1395-1402.

Harwiki \& Mirvaisi, M. (2015). Servant Leadership on Organization Culture, Organizational Commitment, Organizational Citizenship Behavior, and Employee Performance in women Cooperatives. 3, 1395-1402. https://doi.org/10.5267/j.msl.2013.04.010

Hidayah, S. (2018). Role of Organizational Citizenship of Justice and Job Satisfaction on Employee Performance. 9(36), 170-178.

Kasimu \& Zavi, L. M. (2013). Training, Employee Engagement, and Employee Performance: Evidence from Makerere University, Kampala. Uganda Health Sector, 22, 131-140.

Kambiz., \& Mirvaisi, M. (2013). Management Science Letters. 3, 1395-1402. https://doi.org/10.5267/j.msl.2013.04.010

Lebrón, M., Tabak, F., Shkoler, O., Rabenu, E., \& Lebrón, M. (2018). Counterproductive Work Behaviors toward Organization and Leader-Member Exchange: The Mediating Roles of Emotional Exhaustion and Work Engagement Counterproductive Work Behaviors toward Organization and Leader-Member Exchange: The Mediating Roles of Emotional Exhaustion and Work Engagement. Organization Management Journal, 00(00), 1-15. https://doi.org/10.1080/15416518.2018.1528857

Li, X., Sanders, K., \& Frenkel, S. (2012). International Journal of Hospitality Management How LeaderMember Exchange, Job Performance on Work Engagement as a Mediation in Chinese luxury hotel, 31(4), 1059-1066. https://doi.org/10.1016/j.ijhm.2012.01.002

Linda Koopmans. \& Marfa, J. (2014). The role of counterproductive work behavior inefficient management. African Journal of Business Management 15(1), 97-116. https://doi.org/10.1108/13287261311322602

Mafini, C., Africa, S., Mafini, C., Blvd, P., Africa, S., \& Attribution, C. (2014). Investigating antecedent factors to Job Performance: Contemporary evidence from government supply management professionals.1-11. https://doi.org/10.4102/ac.v15i1.287

Madhura\& Ikhwan, K. (2014). IA study on the Drivers of Employee Engagement impacting Employee Performance 30 (7), 1033-1011.

Nawaz, \& Xavier, k. (2014). International Journal of Hospitality Management job performance. International Journal of Hospitality Management, 35 (6), 1059-1066.

Novliadi. (2016). International Journal of Management; Organizational Citizenship Behavior on job performance. , 34 (3), 1052-1063. 
Organ, Kaufmann, H. R., \& Rabino, S. (2018). Relationship between the facets of employee performance and organizational citizenship behavior. The Journal of Faculty of Economics and Administrative Science. Y.2013, Vol. 18, No.1, pp.243-269

Paskin \& Kim, J. (2014). Learning Organization and counterproductive work behavior The mediating effect of work engagement. 38(1), 75-94. https://doi.org/10.1108/EJTD-04-2013-0040

Rosemary, P. (2017). A correlate of Counterproductive Work behavior on Employee Participation in Decision Making. 7(7), 934-948. https://doi.org/10.6007/IJARBSS/v7-i7/3179

Rosdiati, ida. (2018). The impact of Counterproductive Behavior on Employee Engagement. https://doi.org/10.17576/2018-52-03

Rizwan., Yadav, R., \& Choudhary, V. (2014). Analyzing the impact of Employee Engagement and Employee Performance in banking adoption: A study of Indian Bank. International Journal of Bank Marketing, 37(1), 323-339.

Ruky. (2012). The impact of Counterproductive Work behavior on Employee Engagement in Japan bank. https://doi.org/10.6007/IJARBSS/v7-i7/3179

Saeed, A., \& Author, C. (2015). The impact of Work Behavior on Employee Performance in Wuhan, China. $3(1), 475-484$.

Schaufeli. (2013). A study on Employee Engagement Models for the sustainability of Organization. (44), 2319-5479

Sedarmayati. (2016). Impact of Leadership Style on Employee Performance in an organization, 1-28. https://doi.org/10.1037/t09115-000

Shantz, A., Alfes, K., Truss, C., \& Shantz, A. (2015). Employee engagement in the relationship between job design and task performance, citizenship \& deviant behaviors.

Shimazu, A., \& Schaufeli, W. B. (2009). Is Workaholism Good or Bad for Employee Well-being? The Distinctiveness of Workaholism and Work Engagement among Japanese. 495-502.

Shimazu, A., Schaufeli, W. B., Kubota, K., \& Kawakami, N. (2012). Do Workaholism and Work Engagement Predict Employee Well-being and Performance in Opposite Directions ? 316-321.

Uddin., \& Mirvaisi, M. (2018). Management Science of Behavior. 3, 1395-1402. https://doi.org/10.5267/j.msl.2013.04.010

Vathsala \& State, O. (2014). The Effect of Organizational Citizenship Behavior and Employee Engagement as a Meditation on Quality Performance. 5(8), 198-204.

Wickramasinghe, V., \& Perera, S. (n.d.). Total Quality Management \& Business Excellence Effects of perceived organizational support, employee engagement and organizational citizenship behavior on quality performance. January 2015, 37-41. https://doi.org/10.1080/14783363.2012.728855

Yongxing, G., Hongfei, D., Baoguo, X., \& Lei, M. (2017). Work Engagement towards Objective Task Performance in a telecommunications company in southern china 33, 708-713. 